the general conclusions remain as given above. We see that our apparently simple definition of a cell necessarily implies a complexity reminding one of the actual conditions in biological systems ! ${ }^{2}$

An objection has been raised to all the above considerations that, in actual cells, protoplasmic streamings are often observed, which should stir the interior of the cell and even out the concentration gradients. This objection is based on fallacy. Not only does the existence of protoplasmic streaming constitute no argument against the existence of gradients, but it is a positive proof for their existence. Where there are streamings, there are the forces which produce them; and if everything were homogeneous, no such forces could be produced. It is true that the occurrence of streamings will modify the distribution of forces, and so far this complication has not been taken into account; it is one of the next problems on our programme. It has been already suggested that such a further generalisation of the theory may throw light on the mechanism of locomotion in the Protozoa.

Thus far we have been considering the effect of the forces produced by the cell on the cell itself ; but the concentration gradients outside the cell result also in forces between one cell and another. All those forces being of the same origin, there is a close relation between them. Whenever we have an aggregate of cells in which the dividing factors prevail, they will repel each other. On the other hand, when the 'restoring' factors prevail, cells attract each other. Of all cells, the neurones have most completely lost their property of dividing; we should expect forces of attraction between them. Indeed the existence of such forces has been inferred by a number of neurologists, notably Ariens Kappers and Ramon y Cajal, from various observations. The peculiar irregularity in shape of the neurones and the existence of a great number of interneuronic connexions is also to be accounted for by those forces. It has been suggested that a formation of new anatomical connexions between neurones may be the cause of conditioned reflexes and learning. Calculation shows that the above forces may account for it. Under certain conditions they will produce an actual new connexion in a very small fraction of a second.
This leads us towards a mathematical theory of nervous functions. We find that, under very general conditions, aggregates of cells such as are studied above will possess many properties characteristic of the brain. These include differential discrimination of spatial and temporal patterns by learning, and what is known in psychology as 'Gestalt-transposition'. For details we must refer to the original papers'.

Finally, the theory of intercellular forces has been applied to the form of cellular aggregates, forming multicellular organisms. It has been shown that those forces account in a general way for the various stages of embryonic development (blastula, gastrula, neurula), and for the gross features of the forms of various classes of animals ${ }^{5}$.

Having thus started from a study of the most general properties of a cell, we arrive in a deductive, synthetic way at a possible understanding of such problems as "why we behave as we do" and "why we are shaped as we are".

We have not mentioned at all the "mechanism. vitalism' controversy. The problems discussed here are entirely independent of its issue, if there be an issue ${ }^{6}$. Whether the present-day concepts of physics will prove sufficient to provide an exhaustive explanation of life, or whether new principles will be introduced in the future, the treatment of those problems will of necessity be mathematical, if it is to be exact and scientific and not to resolve itself into mere verbal disputes.

Much remains to be done, but there can be little doubt of the fruitfulness of this approach. The further we proceed, the more difficult become the mathematics involved; but the results compensate for all difficulties. C. F. Gauss, "rex mathematicorum", derived many an inspiration for his purely mathematical discoveries from the study of physical phenomena. The time has come when mathematicians may find their problems in the ever-inspiring realm of living Nature.

\footnotetext{
${ }^{1}$ Protoplasma, 14, $99 ; 1931.15,427 ; 1932.16,387 ; 1932$. Physics, 1, 143; 1931 .

${ }^{2}$ Cold Spring Harbor Symposia on Quantitative Biology, 2; 1934

s Physics, l.c.

"Forthcoming in "Philosophy of Science" and in the Journal of General Psychology.

${ }^{5}$ Protoplasma, 20, 180; 1933.

"Cf. concluding paragraphs in "Philosophy of Science", I.c.
}

\title{
Racial Studies in Britain
}

$\mathrm{T}$ HE proposals put forward by the Royal Anthropological Institute for an organised anthropometric survey of Great Britain (see NaTURE, 135,$463 ; 1935$ ) revives a project in anthropological research of which too little has been heard in recent years. It is a project which has had a curiously chequered history; and its fate up to the present has been less than is deserved both by its intrinsic merits and by the enthusiasm and strenuous efforts of those who, from time to time, have endeavoured to bring it to practical effect. The story covers more than half a century 
of the comparatively short history of anthropology as a science.

The racial history of Britain begins in what is now called pre-history with the studies of prehistoric skeletal material by Barnard Davis, Thurnam and Rolleston. From this emerged the concept of a racial succession of long-heads and broad-heads of the stone and bronze ages with the long-headed Saxons and intruding Danes as an overlying element in the building up of the population. Even before the publication of Thurnam and Davis's "Crania Britannica" in 1865, Dr. John Beddoe had been at work in the 'fifties, collecting particulars of hair- and eye-colour in Scotland, Ireland and England, which he was afterwards to utilise in his "Races of Britain". But the first organised attempt at measurement of the living on an extended scale was made by the Anthropometric Committee of the British Association which reported in 1878 and succeeding years and in 1883 published a comprehensive final report, to which reference is sometimes made under the name of its secretary, C. Roberts, who was responsible with Sir Rawson W. Rawson for its compilation. Notwithstanding the lapse of time, and in some instances the uncertainty of conclusions based upon insufficient data, this is still the standard of reference for any comprehensive account of measurements of the living in the British Isles.

Various attempts, mostly somewhat spasmodic, were made to keep alive the work of the Anthropometric Committee. Francis Galton measured 10,000 individuals at the International Health Exhibition of 1884, and a laboratory which he instituted at the South Kensington Museum with an elaborate programme of observations was in existence for some years. From the Manchester meeting of the British Association in 1887 until the Nottingham meeting in 1893, measurements were taken of such of the members of the Association as visited a temporary laboratory set up at each meeting under the care of a committee which reported annually. Other British Association Committees were appointed from time to time. A committee on the measurement of children became a committee for the study of the abnormal and, acting in co-operation with a committee appointed by the International Congress of Hygiene of 1891 , recorded the observation of 30,000 children in 1892-93 and helped to secure the special treatment of the defective child; while a committee to promote anthropometric measurements in schools collected a certain amount of information, aroused some enthusiasm, but failed to initiate any general or extended action. Anthropometric observation also formed part of the extensive programme of a committee for the ethnographic survey of Great
Britain appointed in 1892, which published five reports between that date and 1899, when it ceased to exist in favour of a proposal for an Ethnographic Bureau for Great Britain.

Following this, the most serious effort in pro. moting anthropometric research was made early in the twentieth century by another Anthropometric Committee of the British Association appointed in 1902, which, although it did not carry out measurements on the living as was originally intended, nevertheless had an important influence on the further development of anthropometric observation. This it achieved in the first place by drawing up under the chairmanship of D. J. Cunningham a code of instructions for anthropometric measurement, which, whatever its defects may have appeared to be to a later generation, secured the standardisation of a technique which was in advance of that of its day; and secondly by its efforts, and more particularly the efforts of individual members of the committee, to secure the recognition of an anthropometric survey of the inhabitants of Britain as a work of national importance, which should be supported by a subvention or even undertaken as a national charge.

In the latter of these two activities of the Committee one member was indefatigable. This was John Gray, its secretary throughout the whole of its existence. A native of Aberdeenshire, he had taken up anthropometric work in the 'nineties, when he used to visit the fairs and other countryside gatherings in Buchan and record the physical measurements and characters of those who attended them. His early contributions to anthropometric research were studies of the material thus obtained, which were submitted to the Buchan Field Club. In this work he was soon joined by Mr. J. F. Tocher, then of Peterhead, who made an ethnographical study of the school children of Buchan, which was also communicated to the Field Club. This work had one important consequence. It brought the two men into touch with Sir William Turner, himself a famous craniologist and then professor of anatomy in the University of Edinburgh, through whose influence they were able to obtain financial assistance for their further work of anthropometric survey, one outcome of which was the important and authoritative study of the physical characters of the inmates of the asylums of Scotland.

It is not so much Gray's work as a persistent measurer of heads on all occasions, suitable or otherwise, or his ingenuity in devising 'fool-proof' anthropometric instruments, with which we are concerned here, as with his unobtrusive but determined and unceasing efforts to secure public recognition of the value of anthropometry, more 
especially in its application to the population problem of Britain. A word, however, must be spared for his early appreciation of the significance of biometric methods in anthropology. Like C. S. Myers, whose paper on "The Future of Anthropometry" in 1903 has been regarded as a landmark, he recognised that much early work in physical anthropology was vitiated by the insufficiency of the data on which its conclusions were based, and advocated the employment, and himself consistently employed, sound statistical methods on the lines of Prof. Karl Pearson's work, in the critical treatment of the data of the observer.

It is not proposed here to attempt an examination of the contribution of the biometric school to the racial history of the British population, of which a brilliant example has recently come from the pen of Dr. G. M. Morant. For one reason it stands somewhat outside the movement now under consideration, though, it is to be judged, under the present proposals of the Royal Anthropological Institute, a more or less complete fusion of material from both sides will now take place.

At about the time of the appointment of the last-named of the Anthropometric Committees of the British Association mentioned above, the people of Great Britain were much alarmed, so far as was to be gauged from the daily Press, by the alleged fact of a serious physical deterioration in the population and a marked inferiority of development among the children of the less well-to-do in the community. In part this was an aftermath of the Boer War, not unconnected with difficulties in recruiting for the Army. Largely as a result of newspaper agitation, an InterDepartmental Committee was set up to inquire into the matter. Among those invited to give evidence before this Committee were several anthropologists, including D. J. Cunningham, chairman of the Anthropometric Committee and by now professor of anatomy in the University of Edinburgh.

The Inter-Departmental Committee issued its report in 1904. Almost immediately afterwards the British Association met at Cambridge, where a full-dress discussion of the situation took place in Section $H$ (Anthropology) under the presidency of Mr. Henry Balfour, at which the Right Hon. Arthur J. Balfour (afterwards Earl Balfour), then Prime Minister and president of the Association, was present. The most noteworthy features in the discussion were a doubt expressed by Arthur Balfour whether, judging from his own experience on his estate in Scotland, the conditions in rural areas were such as to conduce to the superiority in physique usually attributed to the countryman over the town population, if such superiority were a fact, and the conclusion, drawn from his observations of hair-and eye-colour, by Dr. F. C. Shrubsall, that residence in urban areas favoured the dark as against the fair element in the population, and that this might possibly bear upon the incidence of disease, especially tuberculosis and cancer.

The question raised in the discussion by the president of the Association served to emphasise the fact, already made patent in the report of the Inter-Departmental Committee, that there was a paucity of relevant measurement upon which any conclusion as to physique could be based. Broadly stated, however, the conclusion of the Inter-Departmental Committee was that there was no evidence of organic, extensive or permanent physical deterioration in the population as a whole.

It was clear that this conclusion rested, for the most part, upon expressions of opinion, wellfounded, no doubt, rather than upon the evidence of extended and comparative series of measurements. These did not exist, except in so far as afforded by the British Association Committee's reports. Other figures brought forward afforded no certain basis of comparison. For children and adolescents, it is true, restricted series were available such as the measurements of the boys of Marlborough, where the annual anthropometric reports of Mr. E. Meyrick were a feature of the Field Club magazine for many years, and of Manchester Grammar School, but little was known of the working-class child-population.

Anthropologists were not slow to point out the defects of the report, and they emphasised the futility of discussion of groups of measurements from specific areas, or social groups, whether of adults or of children, unless a norm, or standard of normal development, or a series of such norms, had been established for the country as a whole and, more especially, for the various racial groups of which the population was composed. So far as the measurement of children was concerned, the anthropologists joined forces with the educationists and every effort was made by deputation and otherwise to bring their views to the notice of the Government of the day. Arrangements were made for a joint discussion between the Anthropological and Educational Sections of the British Association to take place at the Leicester meeting in 1907, in which even that distinguished authority on the school child, Prof. J. Munsterberg, was prepared to join. But when the meeting took place, its thunders had been stolen. In the course of the debate, Mr. Ramsay Macdonald, the leader of the Labour Party, who had promised to speak in support of a demand for Government action, was able to report that the previous night, or rather in the early hours of that morning, a Bill 
for the medical inspection of school children had passed its third reading in the House of Commons. For the success of this measure Sir Philip Magnus, the educationist, representative in Parliament of the University of London, had been largely responsible.

The self-congratulations of the anthropologists on this measure were premature. While recognising its value, and well aware of the benefit which, as time has shown, it was to confer on the people, when the Act came into operation, they noted with regret that no provision was made for anthropometric measurement as a general operation, and no attempt was made to set up a racial standard or standards against which to measure the abnormal or under-developed. The results may be seen in some of the general conclusions put forward, especially in connexion with the effects of malnutrition, in early reports by medical officers who had not appreciated the finer points, patent to the anthropologist, in handling their material.

From this time forward, the project of a nationwide anthropometric survey, though not sinking entirely into oblivion, became less prominent. It merged into larger proposals which the Royal Anthropological Institute contemplated promoting, while the untimely death of John Gray in 1912 and the outbreak of War helped to relegate it still further to the background in which stood the many desirable things which were to await more propitious times.

In the meantime, also, active interest in anthropometric research had shifted to the regional surveys which were being carried out by individual workers, singly or in groups, and this up to the present has continued in the post-War period. Of these surveys, it is not possible to refer in detail and mention must be confined to one or two, such as that carried out by Prof. H. J. Fleure and his colleagues and pupils in Wales, of which an early report was presented at the Sheffield meeting of the British Association in 1910, the work of Prof. F. G. Parsons and his helpers in the Chilterns, which he has linked up with wider aspects of
British ethnology especially in connexion with skeletal material from London and, more recently, Miss R. M. Fleming's continuous periodical measurements of school children in Wales, and her study of hybrids.

The work carried out by Prof. Fleure, or under his inspiration, is especially important in connexion with the proposal which has been put forward by the Royal Anthropological Institute. Working with Aberystwyth as centre, Prof. Fleure and his pupils have demonstrated the relation of racial history to a number of sociological and economic problems. Of these investigations, not the least suggestive, from the point of view of practical politics, is the attempt to correlate, on scientific evidence above cavil, racial constitution and the incidence of disease.

Apart from its practical applications, to which due weight must be given when public assistance is sought, to the anthropologist the most pregnant feature in Prof. Fleure's work has been the demonstration of restricted areas in which has been found what appears to be the survival of a primitive-in some instances an extremely primitiveform among a population essentially modern in character. In this his work links up with the more subtle interpretation of the prehistoric skeletal remains which began, perhaps, in the opening years of the century with Prof. T. H. Bryce's survey of the prehistoric population of the shortcist graves of the Isle of Arran and the identification, soon afterwards, of the Beaker type, in the broad-headed skulls found in the neighbourhood of Aberdeen. As Prof. Fleure has again pointed out recently, the broad generalisations of racial history in Britain, however true at a certain level of thought, may mask rather than reveal facts of which a detailed view is needed. In linking up the prehistoric data with those relating to the modern population, the survey which the Royal Anthropological Institute contemplates will carry on methods of study which, as received from the hands of Prof. Fleure, have already had a profound effect in their application to racial problems in areas other than Wales.

\section{Obituary}

Prof. J. J. R. Mácleod, F.R.S.

$\mathrm{B}^{\mathrm{r}}$ the death after a long illness, on Saturday, March 16, of J. J. R. Macleod, regius professor of physiology in the University of Aberdeen, medical science has lost an outstanding worker.

John James Rickard Macleod, a son of the manse, was born at Cluny, near Dunkeld, on September 6, 1876. $\mathrm{H}_{\Theta}$ was educated at Aberdeen Grammar School and at the University of Aberdeen. $\mathrm{He}$ completed a distinguished undergraduate career by graduating M.B., Ch.B. with honours in 1898, being awarded at the same time the Anderson Travelling Scholarship. He worked for the next year in Germany, in the Institute of Physiology at Leipzig. In 1900 he was appointed demonstrator in physiology at the London Hospital Medical College and in 1902 was promoted to be lecturer in biochemistry. In 1901 he had been elected to the Mackinnon Scholarship of the Royal Society. He was appointed in 1903 to the chair of physiology at the Western Reserve University, 